\title{
ドローンを用いた屋根表面の温度分布の評価
}

\author{
河村 進* 中井 毅尚**

\section{Evaluation of Roof Surface Temperature Distribution Using a Drone}

by

\author{
Susumu Kawamura* and Takahisa NAKAI**
}

To evaluate the temperature distribution of a roof receiving sunlight, we investigated a measurement method using a drone equipped with thermography. Since the number of pixels and shape of the contour of the captured roof images depend on the angle at which the photograph is taken and flight altitude of the drone, we standardized images into the same coordinate system by placing positioning markers on the roof before image capture. The visible image and temperature data for the roof were projective transformed. Differences in temperature measured by thermography and thermocouples attached to the roof were within the temperature accuracy range of thermography. Changes in roof surface temperature could also be measured by a thermograph mounted on a drone. We confirmed differences in temperature distribution among roof materials and part types, in part due to the uneven surfaces of the roof tiles.

\section{Key words:}

Drone, Infrared thermography, Image transformation

1 緒言

我々は日射が屋根表面や室内などの住宅各部位に与え る影響を評価するため，実大サイズの木造実験住宅を対 象として, 熱電対とデータロガーを用いた測定を行って いる ${ }^{1)}$. しかし，高所である屋根に熱電対を貼り付けて測 定すると, 風雨にさらされた熱電対が仮に屋根表面から はがれたとしても，地上から確認することは極めて困難 であった。また，データロガーを用いた従来法では，測定 点数の制限から屋根全体の温度分布を詳細に確認するこ とはできなかった. 今後，中大規模木造建築物の普及拡大 が想定される中で, 屋根全体の温度分布を従来法で把握 することは益々困難になると予想される．

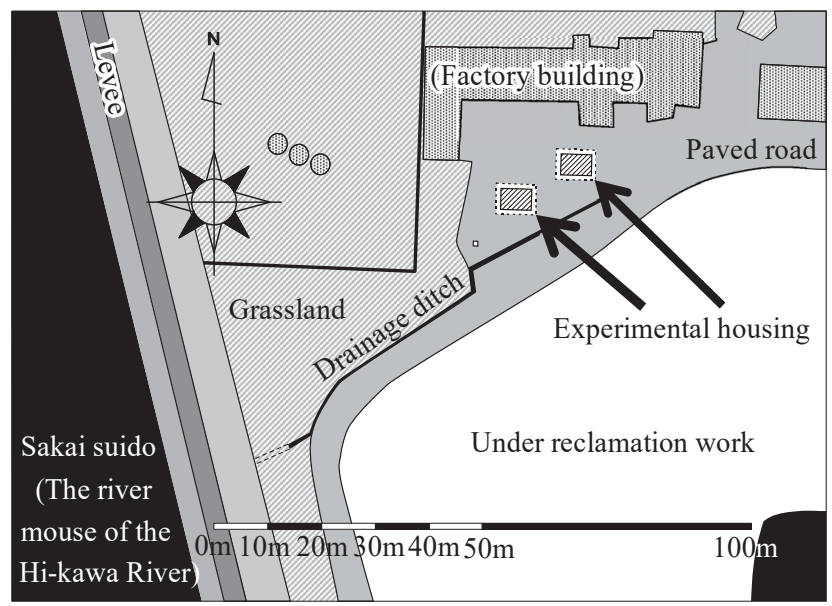

Fig. 1 Location map and arrangement of experimental housing.

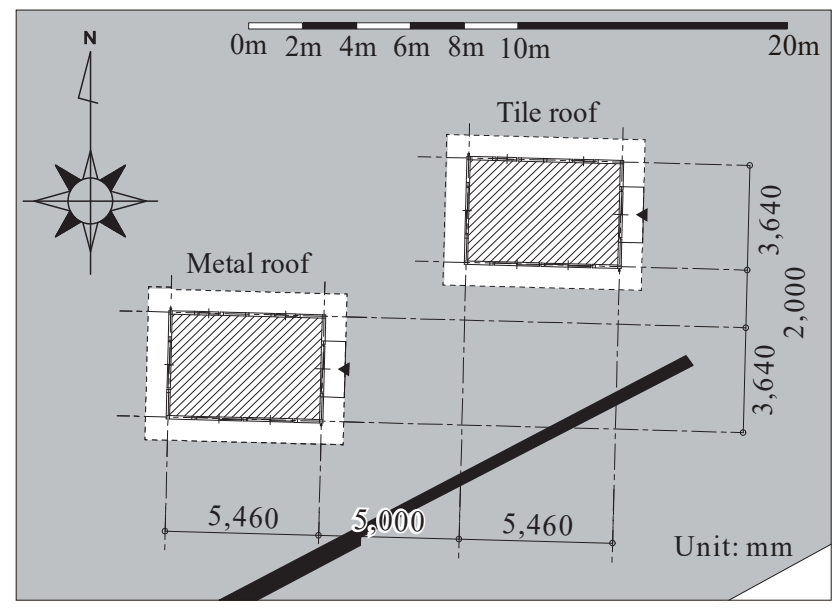
こうした状況に対して, 我々はサーモグラフィー (遠赤 外線撮影素子）を搭載したドローンを，屋根の点検や表面 温度の測定に応用すれば，木造実験住宅の屋根表面に貼 り付けた熱電対の状態を確認するのみならず, 屋根全体 の温度分布を確認することも可能になると考えた．現在， ドローンによる点検は, 屋根に設置した太陽光パネルの 保守点検において普及が進みつつあるが 2), 大量の撮影画 像から測定箇所を特定する手順の確立は未だ十分とは言 えない. さらに, 一般的な建築物件の外皮温度測定にドロ ーンによる測定を適用する場合，画像解析の手法に何ら かの工夫が必要である.

そこで本研究では，比較的低価格で，サーモグラフィ 一を搭載したドローンによる撮影や，撮影した画像から

(C)2021 The Society of Materials Science, Japan

$\dagger$ 原稿受理 令和2年11月17日 Received Nov. 17, 2020

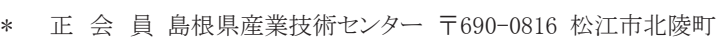

Shimane Institute for industrial Technology, Hokuryo-cho, Matsue 690-0816.

** 正 会 員 三重大学大学院 生物資源学研究科 $\bar{T} 514-8507$ 津市栗真町屋町

Mie University Graduate School, Faculty of Bioresources, Kurimamachiya-cho, Tsu 514-8507. 

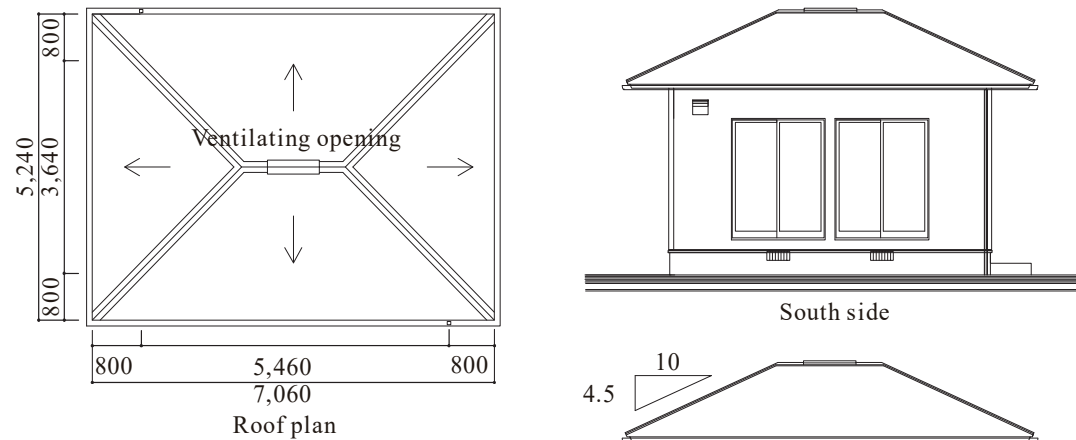

South side
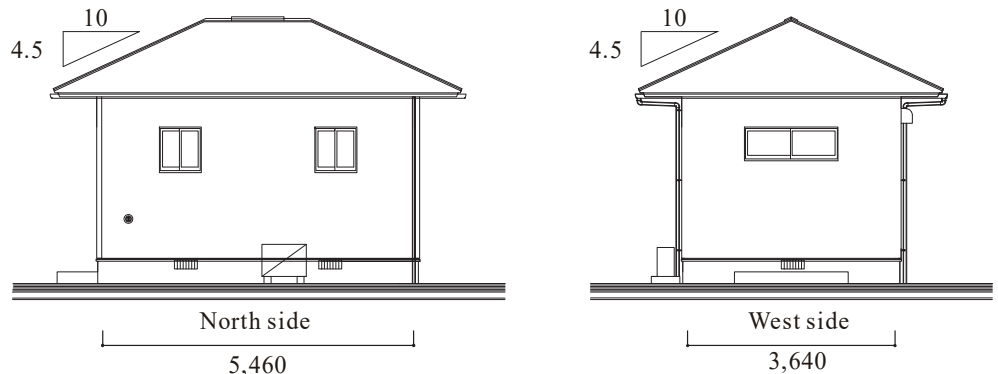

- Sekisyu roof tile for tile roof of experimental house, or galvalume steel plate for metal roof of experimental house

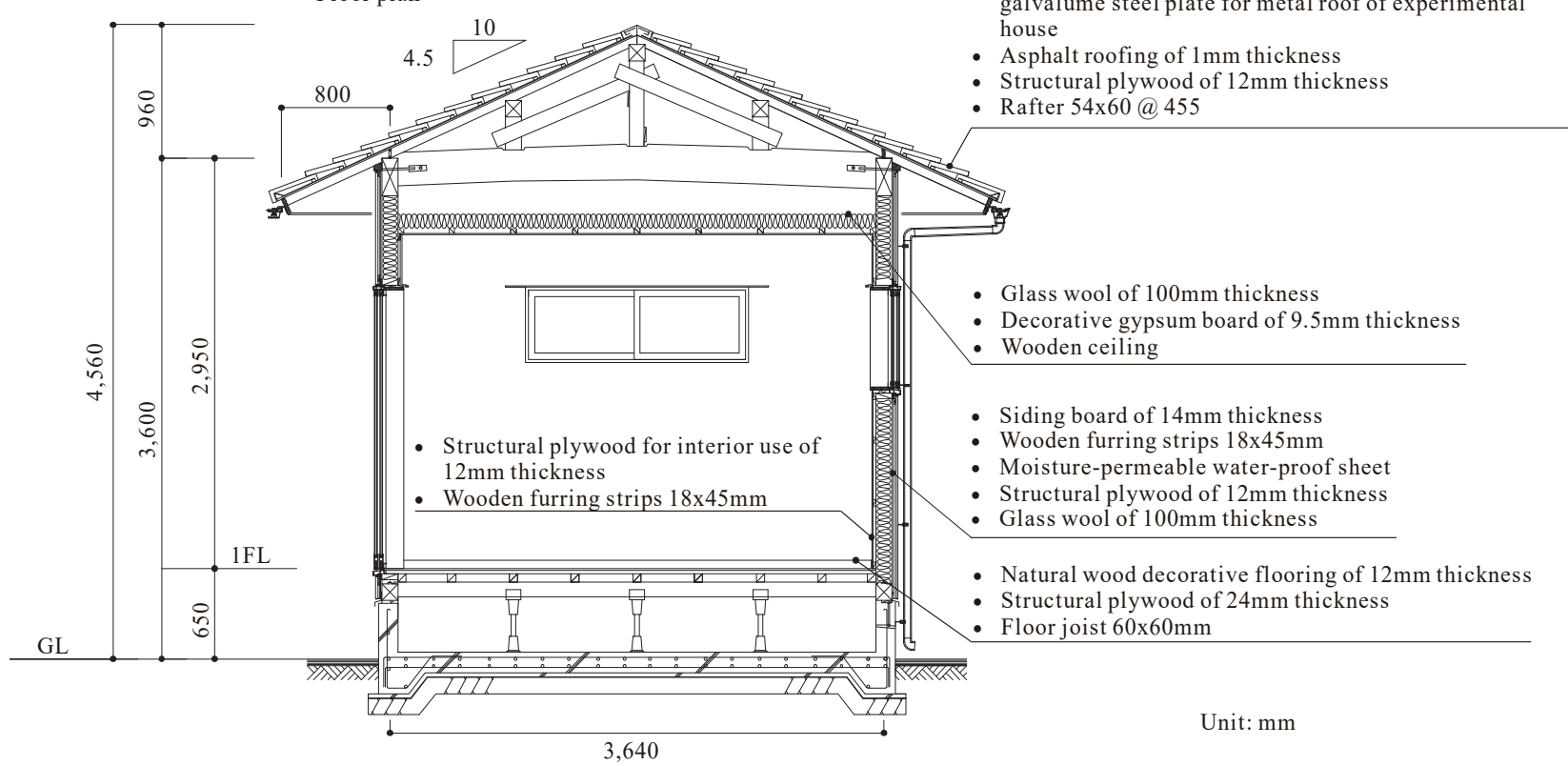

Fig. 2 Detailed dimensions of the experimental house.

屋根表面温度の分布を取得し，屋根莫き材料の材質・部 位・形状の違いによる温度分布の評価を行った。

\section{2 方 法}

\section{1 試験体}

測定対象の実験住宅は工場敷地（鳥取県境港市西工業 団地，日新林業(侏境港工場）に立地し, Fig. 1 に示すように 同一寸法で, 屋根材を瓦屋根（石州釉薬瓦・ $\mathrm{J}$ 形・株丸惣 製）と金属屋根（55\%アルミ亜鉛合金メッキ鋼板・日鉄鋼 板(株製) とした 2 棟の住宅が外壁間距離で東西方向に $5 \mathrm{~m}$, 南北方向に $2 \mathrm{~m}$ 離れて建てられている. 住宅の詳細寸法を Fig. 2 に示す.

\section{2 ドローンによる撮影}

本研究に用いたドローンは Parrot 製 ANAFI Thermal で ある．昼間の時間が長く，一日にわたって晴天が続いた 2020/8/20 に測定を行った. 測定当日の気温, 相対湿度, 全 天日射量，および風速の変化を Fig. 3 に示す．なお，航空
法第 132 条の 2 第 7 号では無許可でドローンを第三者か ら $30 \mathrm{~m}$ 未満の距離で飛行させることが禁止されており ${ }^{3)}$, 許可を受ける機体は万一に備えた構造上の安全要件 4)を 満たす必要がある。 そこで, 本研究では Fig. 4 に示すよう なプロペラガードを取り付ける改造を行い, 国土交通省 大阪航空局より承認をうけて実施した.

前述したようにサーモグラフィーを搭載した本ドロー ンでは, 可視画像を熱画像に重祆合わせて記録できる. 非 冷却マイクロボロメーターを用いた本サーモグラフィー の温度精度は測定レンジ $\left(-10 \sim 140^{\circ} \mathrm{C}\right)$ に対して $\pm 5 \%$ $\left(7.5^{\circ} \mathrm{C}\right)$ であるが，屋根の温度分布の測定については適 用の可能性が期待された。

熱画像の撮影に際しては, 離陸させたドローンを地上 から 16〜22m の高さでホバリングさせ, 屋根全体を画角 に収めた熱画像を 10 秒ごとに各屋根 5～10 枚撮影したの ち着陸させた．航空法において無許可で飛行が認められ るのは日の出から日の入り（当日の撮影地点では 5:29〜 

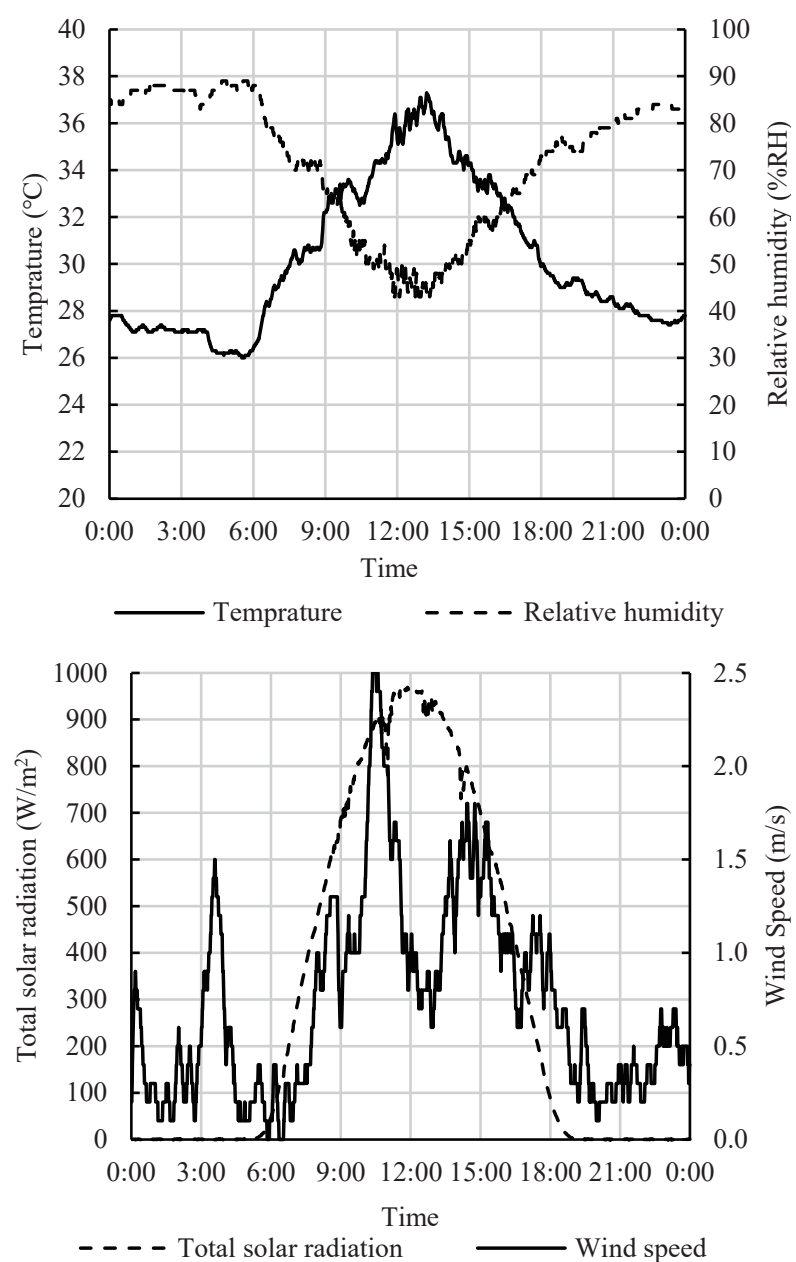

Fig. 3 Changes in temperature, relative humidity, total solar radiation, and wind speed on the day of measurement (August 20, 2020).

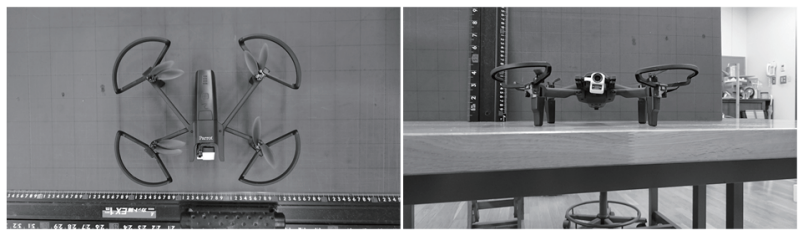

Fig. 4 Attaching the propeller guard to the drone.

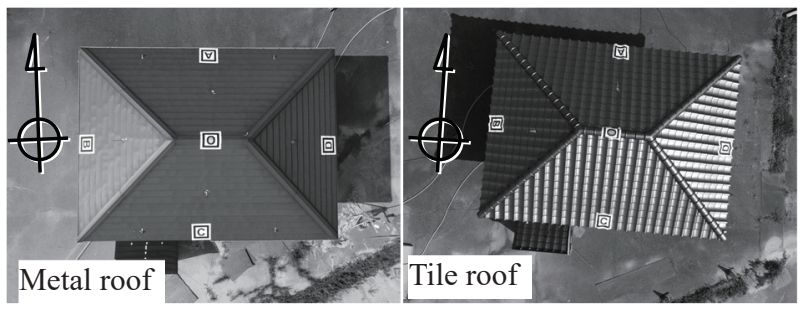

Fig. 5 Attaching markers to the roof and examples of a visible image taken.

18:52)であることから, 本研究では 5:30～18:30 の間に 30 分毎に撮影を行った。ただしバッテリーが過熱して充電 不良が生じたため, 12:00〜12:30 の熱画像は取得できなか った.

\section{3 画像内における屋根位置の検出}

撮影した合計 372 枚の熱画像から, 解析ソフト (FLIR Systems 製 FLIR Tools）（以下, FLIR Tools と記載する）を

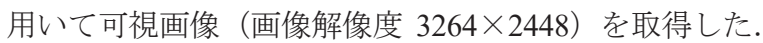
FLIR Tools には熱画像を一括処理する機能がないため，マ

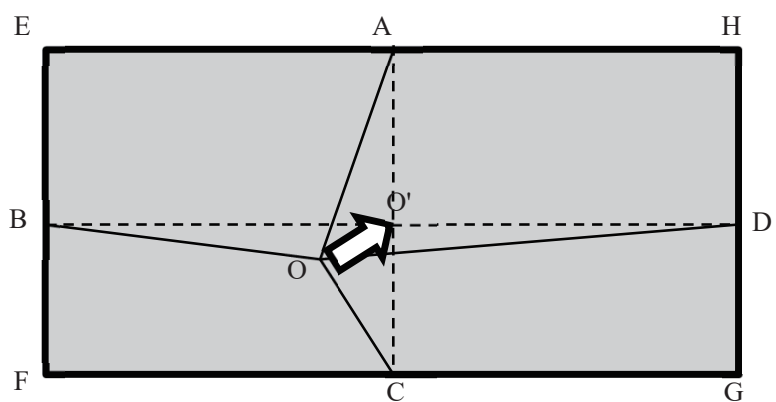

Fig. 6 Concept of projective transformation for roof surface. Note: For example, each coordinate in the figure BOCF on the roof surface was projected and transformed on the assumption that it moved to BO'CF. The same projective transformations were performed for the figures EAOB, AHDO, and ODGC.

ウスおよびキーボードを自動操作するプログラム（以下， 自動操作ツールと記載する）を作成し, 可視画像の取得を 行った。

撮影した屋根の可視画像は, 撮影位置や高度の違い, さらにドローンが風にあおられると傾斜した姿勢から撮 影されたことによってその画角は異なっていた。 そこで， 撮影された屋根形状が屋根伏図と同じ縦横比で，かつ画 像中央部に表示されるよう形状補正を行い, 熱画像に対 しても同一の手順により形状補正を行うことにした．画 像内の屋根位置を検出できるよう, Fig. 5 に示すように測 定に先立って画像マ一カー “A”, “B”, “C”, “D”, “O”を印刷した $440 \mathrm{~mm}$ 角の紙を屋根各辺の長手方向中 心に貼り付けて撮影を行った. 取得した可視画像ファイ ルを画像センサ（OMRON 製 FH-3050）に読み込ませて， 画像マーカーの中心座標をサブピクセル単位で出力した. なお, マーカーが自動検出できなかった撮影画像につい ては目視により座標を読み取った。

\section{4 射影変換による屋根の形状補正}

画角が異なる複数の屋根画像を同一画角の長方形の屋 根に形状補正するため，マーカー“A”〜“D”を同一座 標に移動させる射影変換を行い，屋根の輪郭が同一座標 に配置される可視画像を生成した，射影変換にあたって は, 画像ごとに 2.3 節で得られた座標と補正後の座標を与 えて行列計算を行った。

射影変換は平面困形を対象としたものであるが，本研 究で撮影した画像は 3 次元形状の屋根面である。したが ってマーカー “A”〜“D”により形成される平面上（す なわち屋根輪郭近傍）の点群については射影変換により ほぼ同一座標に移動したが，屋根面内部の点群について は同一座標には移動できなかった. 特に, 補正後の画像の 中心座標に位置すべきマーカー“O”の位置が, 補正後 の画像中のマーカー “A”〜 “D”の平均座標から大き くずれていた.

そこで，“A”〜“D”の 4 点を用いて射影変換した屋 根画像では Fig. 6 に示すように屋根輪郭の 4 頂点が “E”， “F”，“G”，“H”に移動したと考え，“A”，“B”， “C”, “D” の 4 点と屋根輪郭の 4 頂点 “E”, “F”, “G”，“H”，および屋根の中心“O”の座標を結ぶ 4 つ の四角形（EAOB, AHDO, BOCF, ODCG）が，それぞれ各 
頂点の角度が 90 度をなす長方形（EAO'B, AHDO', BO'CF, O'DCG）に変形するよう再度射影変換を行ったところ, 屋 根面内部の座標についてもほとんどの画像が同一座標に 移動した。ただし $\mathrm{AO}, \mathrm{BO}, \mathrm{CO}, \mathrm{DO}$ の境界線上の画素が久 落した画像については, 周囲の画素から補間を行った.

マーカー座標の検出エラーや, 著しい画角の違いによ り屋根の可視画像が同一形状にならなかった画像を除外 して, 測定時刻 30 分毎に撮影した画像から瓦屋根 177 枚, 金属屋根 169 枚の画像を解析対象として抽出した.

\section{5 熱画像からの温度測定値の取得}

解析対象として抽出した熱画像から温度測定值 (横 302 点×縦 228 点) を取得した. 温度測定值の取得に際しても FLIR Tools，および自動操作ツールを用いた。

温度測定值の取得に先立って, 撮影した熱画像の放射 率を補正した。撮影時は屋根莫き材の放射率が不明であ ったので, 放射率 1.00 を設定して撮影を行った熱画像に 対して, FLIR Tools 上で屋根莫き材の放射率（瓦屋根 0.87 , 金属屋根 0.90）を入力した. 放射率の測定に際してはフー リ工変換赤外分光光度計（日本電子製 JIR-WINSPEC100） を用い, 試料表面温度が $40^{\circ} \mathrm{C}$ のきの $8 \sim 14 \mu \mathrm{m}$ (ドロー ンに搭載された遠赤外線撮影素子の検出波長範囲）にお ける積分放射率を算出した。

\section{6 温度分布の形状補正}

2.5 節によって得られた温度測定值に対して 2.4 節と同 様の手順により座標変換を行った。この座標変換により, 屋根面に貼り付けたマーカーによって囲まれた水平投影 寸法 $6620 \mathrm{~mm}$ （東西方向） ×4790mm（南北方向）の領域 は, 建物周囲を含めて撮影した熱画像（横 302 点 $\times$ 縦 228 点）の中心, 横 246 点 $\times$ 縦 178 点の長方形座標範囲に配置 され，計測点 1 か所（1 画素）あたりの水平投影寸法は $26.91 \mathrm{~mm}$ 角となった. さらに, 計測点 1 か所ごとの温度を 測定時刻 30 分毎に平均した.

\section{7 屋根の部位ごとの温度の平均}

2.6 節によって得られた計測点ごとの温度分布を用いて, 東西南北の屋根面各部位の温度を比較するため, 熱画像 において各部位が占める座標範囲を設定した。表面温度 を測定するため屋根面中央付近 1 か所に貼り付けた $\mathrm{T}$ 熱 電対（福電製 T-HVVF）付近, 部屋の上方, 軒部（部屋か ら屋根が張り出した部分）, 屋根面全体（=部屋の上方十 軒部）について, 座標範囲内の計測点の温度を平均した。

温度を平均した対象部位を網掛けして, 座標変換した 可視画像とあわせて Fig. 7 に示す. 金属屋根を座標変換し た画像では, 想定した長方形の屋根輪郭に対して北西隅 および南東隅の頂点がずれるなど，屋根形状が正確には 形状補正できていないが，これは屋根に貼り付けた位置 決めマーカーが所定の位置からずれたことが原因として 考えられる. また, Fig. 8 に示すような熱電対の貼り付け に用いた接着剤や養生テープの範囲を撮影画像から検出 することは困難であったので, 本研究では熱電対付近の $30 \times 30$ 画素（水平投影寸法 $807 \mathrm{~mm}$ 角）の温度を平均すれ ば接着剤や養生テープの影響は無視できると考え, これ を本研究における熱電対貼り付け位置付近における温度 と定義した。

\section{3 結果と考察}

\section{1 屋根面の温度変化の推移}

可視画像にサーモグラフィーで測定した温度分布を重 ね合わせた結果を Fig. 9 に示す.いずれの屋根についても

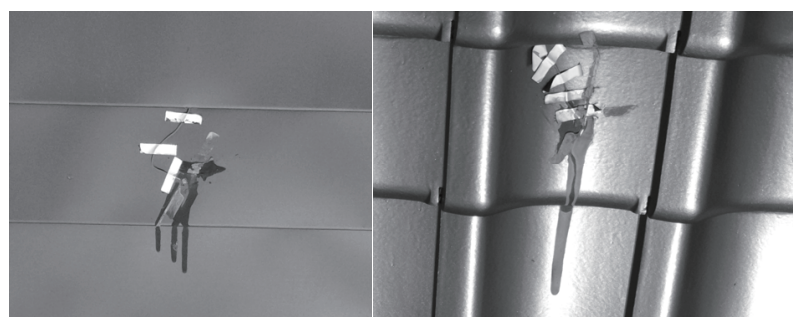

Fig. 8 Thermocouple attachment status on the south roof surface (Left: Metal roof, Right: Tile roof).

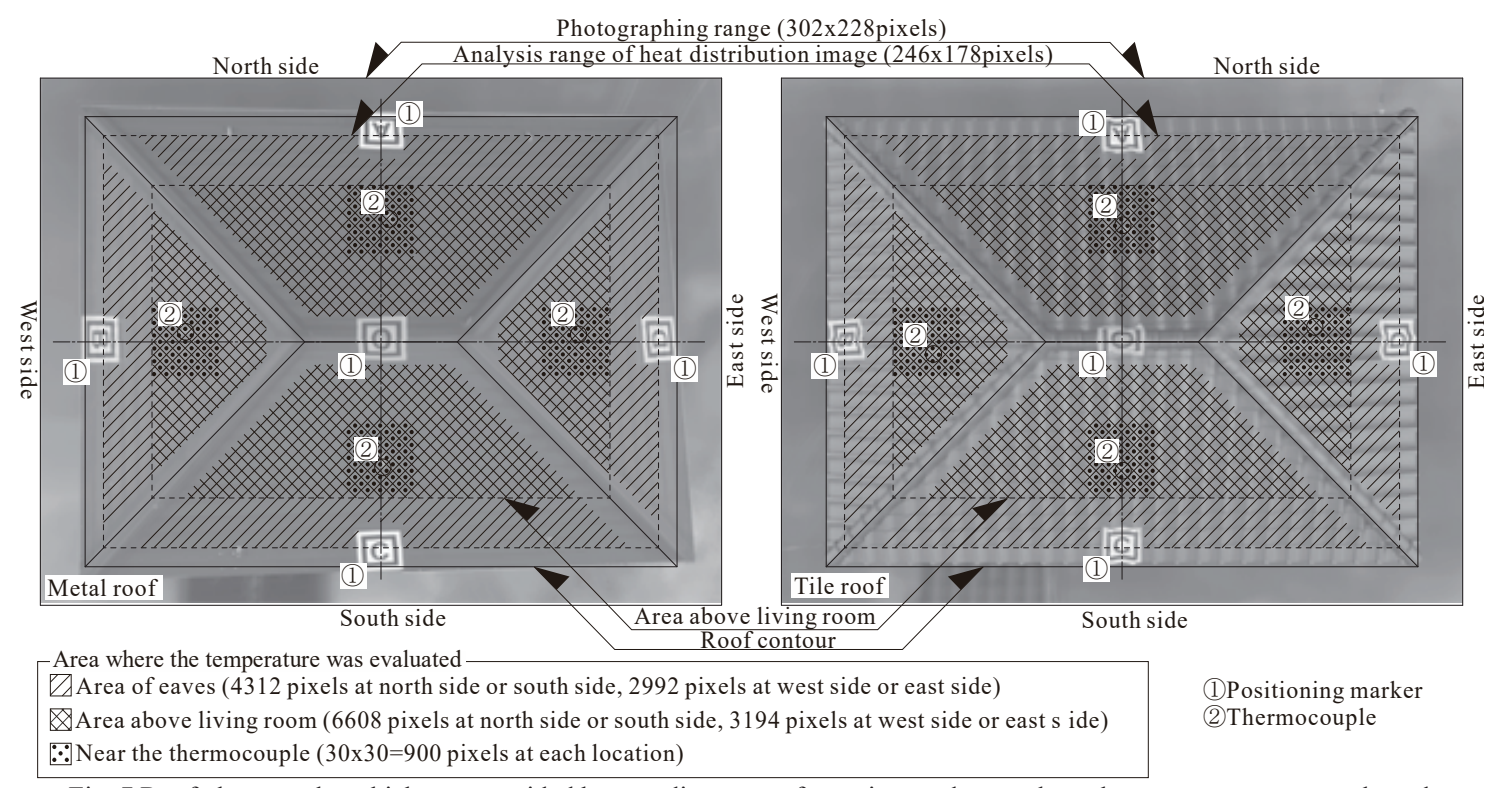

Fig. 7 Roof photography which was provided by coordinate transformation, and area where the temperature was evaluated. 


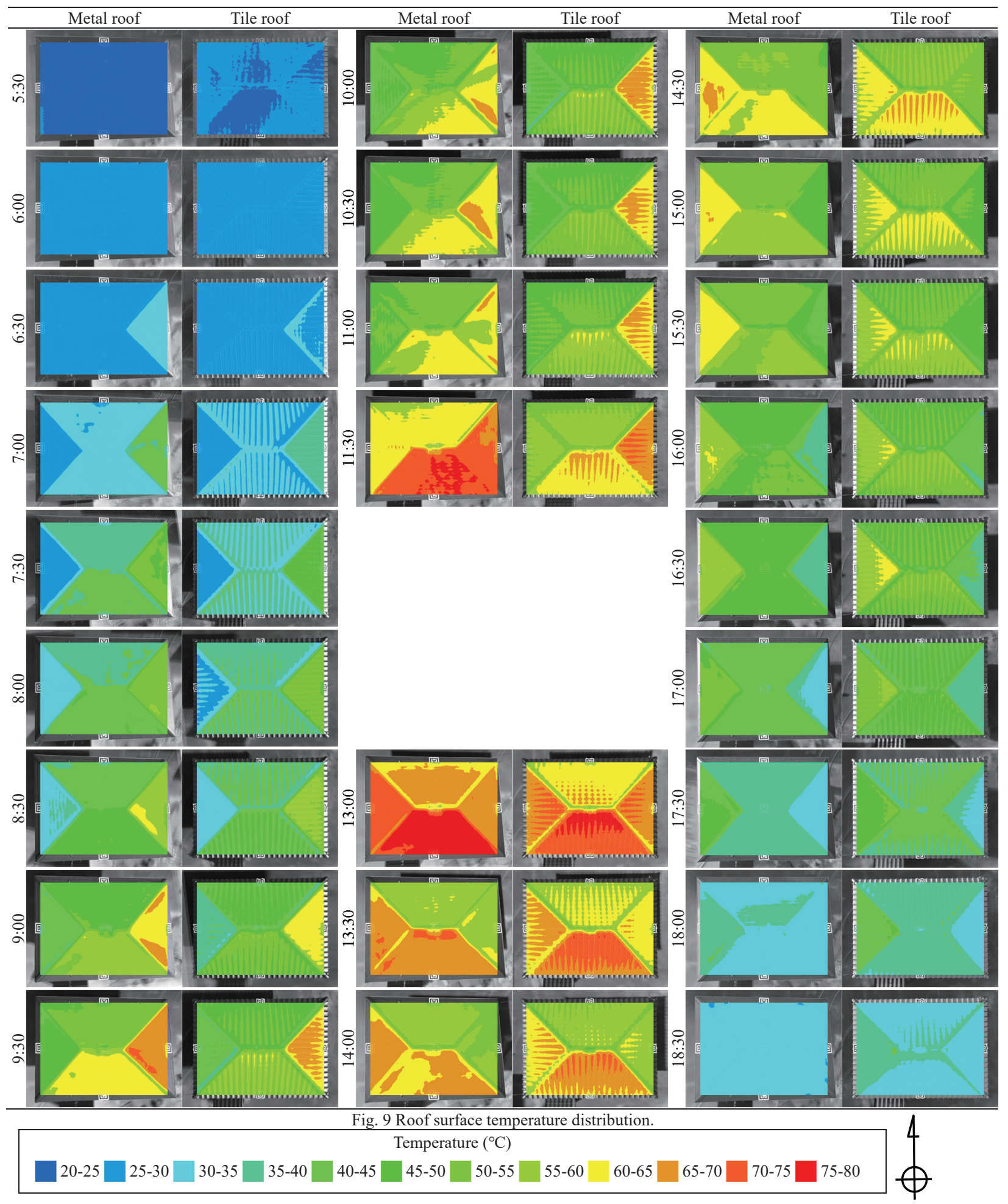

太陽光の入射方向に応じて温度上昇は異なった。すなわ ち, 朝は東側屋根の温度上昇が大きく, 次いで南側屋根 の温度上昇が卓越し, 夕方にかけて西側屋根の温度上昇 が持続した。

いずれの屋根についても，軒部と比較して屋根面中央 の棟瓦付近の温度は高く, 部屋周辺より屋根面中央付近 の温度が上昇しやすい傾向が示された。
3.2 サーモグラフィーによって得られた温度分布と熱電 対で得られた結果の比較

凹凸が少ない金属屋根と比較して，瓦屋根の凹部と凸 部の温度上昇は異なった。一例として, 10:00〜14:00にお ける南側および北側屋根の熱電対貼り付け位置付近 $30 \times$ 30 画素（水平投影寸法 $807 \mathrm{~mm}$ 角）における温度分布を Fig. 10 に示す. 金属屋根ではいずれもほぼ一様な温度で あったのに対し，瓦屋根では $3.3 \sim 8.8^{\circ} \mathrm{C}$ 温度差が生じた。 特に午前中周辺より低温を示した部分が，午後になると 周辺より高温となった。 これは，凹凸面を有する瓦に対し 
て太陽光の入射角度が変化することが理由として考えら れる.ただし, 本研究で撮影した瓦 1 枚（働き幅 $275 \mathrm{~mm}$ ×働き長さ $225 \mathrm{~mm}$ ）の熱画像における解像度はけた行き 方向 10 画素 $\times$ 流れ方向 8 画素（水平投影寸法 $269 \mathrm{~mm} \times$ $215 \mathrm{~mm}$ ) 程度であり, 座標変換精度を考慮すると十分とは いえない，瓦の凹部と凸部の温度変化の推移を評価する には，画像マーカーを増やして拡大撮影を行い，さらに 検討を行う必要があると考えられる。

Fig. 11 に熱電対の貼り付け位置付近における, 熱電対 で測定した温度変化，およびサーモグラフィーで得られ た温度の平均值の変化を示す. 熱電対で測定した温度に 対して, サーモグラフィーで得られた温度は平均 $2.0^{\circ} \mathrm{C}$ 差 が生じたが，これは素子の精度が理由として考えられる。 誤差は生じたものの熱電対とサーモグラフィーで得られ

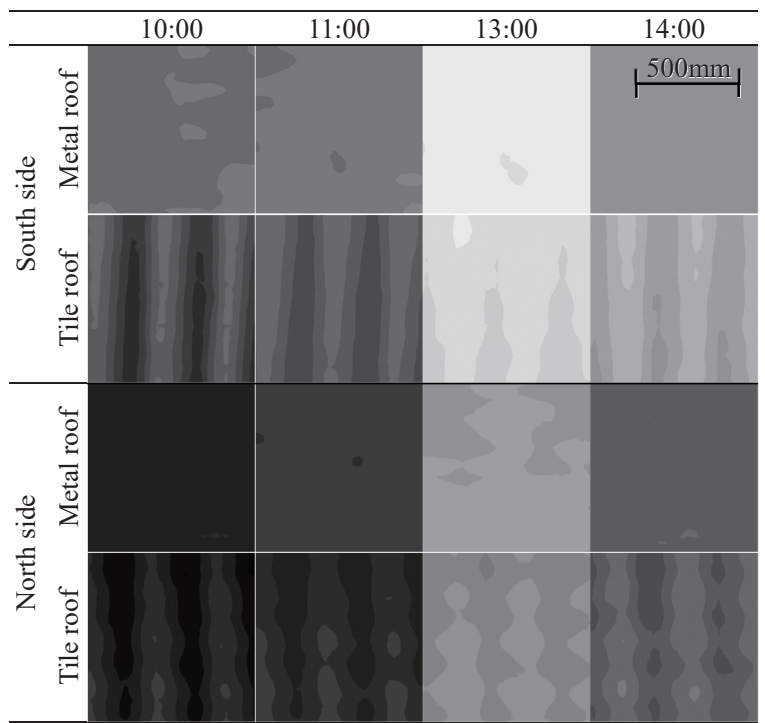

Fig. 10 Temperature distribution near the thermocouple.

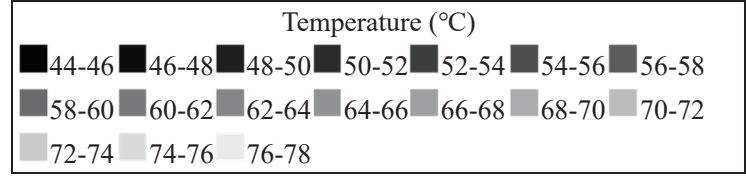

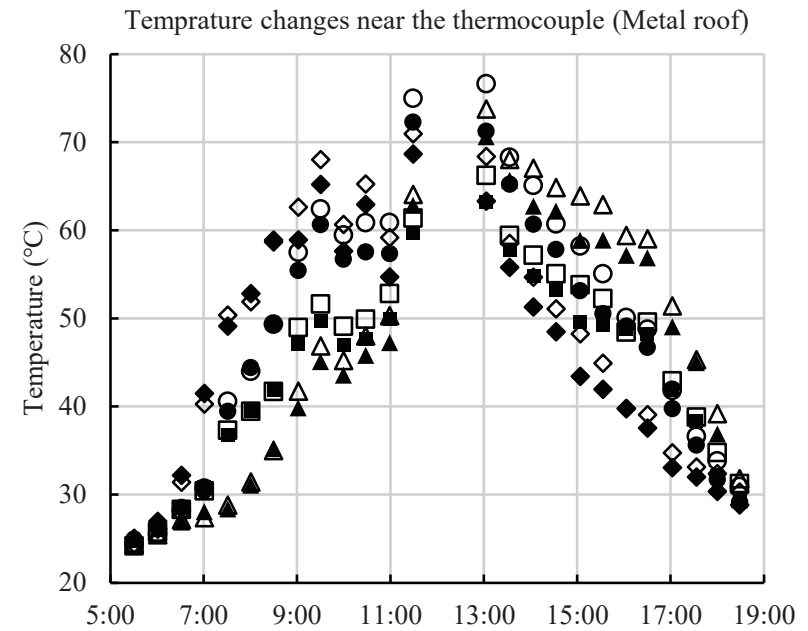

た温度変化は同様の推移を示した。測定レンジに対する 精度が $7.5^{\circ} \mathrm{C}$ である本ドローンを用いても, 位置決め手法 を確立すれば, 屋根面の温度変化は測定可能と考えられ る.

\section{3 屋根の部位による温度の比較}

Fig. 12 に, 熱電対の貼り付け位置付近の温度に対する, 軒部温度, および屋根全体の温度との差を示す. 熱電対の 貼り付け位置の温度が上昇すると, 軒部温度 (Fig. 12a, Fig. 12c），および屋根全体の温度（Fig. 12b, Fig. 12d）は熱電 対付近温度より低くなる傾向を示した. 屋根全体と比較 して軒部の温度差は大きく, 瓦屋根の軒部 (Fig. 12c) で最 も顕著な傾向を示した. 金属屋根（Fig. 12a, Fig. 12b）の近 似直線の傾きはほぼ平坦，すなわち屋根面の温度が高く なっても, 熱電対付近温度と軒部温度, あるいは屋根全 体の温度との差は小さい結果となった。これは熱伝導率 が大きな金属では屋根全体が一様に昇温あるいは放熱し ていることが理由として考えられる．熱伝導率が低い瓦 屋根の表面温度上昇を抑えるには，瓦と下地材との空気 層の有効活用など, 放熱に関して何らかの検討が必要と 考えられる.

\section{4 結 言}

屋根蒀き材が異なる屋根面の温度について, 本研究で はサーモグラフィーを搭載したドローンを用いて夏季の 温度変化を測定した．屋根莫き材によって屋根の表面温 度変化が異なることは熱電対を用いた測定によってもあ る程度確認されていたが, 本研究によって屋根面全体の 状態を把握することが可能となった。

本研究において取り組んだドローンを用いた測定やデ 一夕解析という手法について, 法規制の遵守や膨大な画 像処理といった従来の測定方法とは異なるさまざまな課 題もあったが，測定に伴う高所作業の低減という観点か らは今後利用が進むことが考えられるので，ドローンを 含めた測定系の性能向上に期待したい.

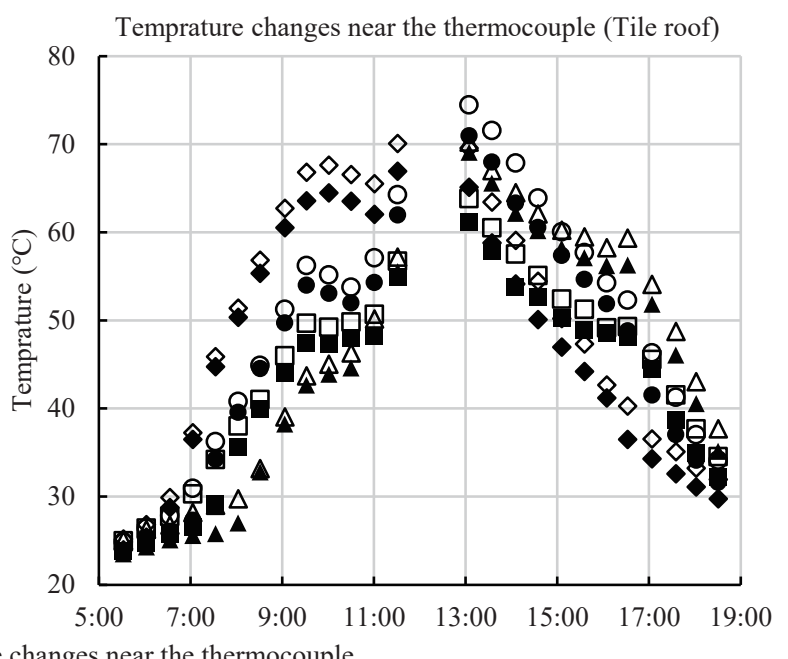

\begin{tabular}{|c|c|c|c|c|}
\hline 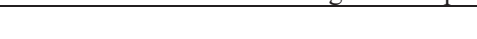 & North side & West side & South side & East side \\
\hline $\begin{array}{l}\text { Temperature using infrared thermography } \\
\text { Temperature using thermocouple }\end{array}$ & a & $\Delta$ & 0 & $\bullet$ \\
\hline
\end{tabular}


a $\begin{gathered}\text { Difference in eaves temperature with respect to the } \\ \text { temperature near the thermocouple (Metal roof) }\end{gathered}$
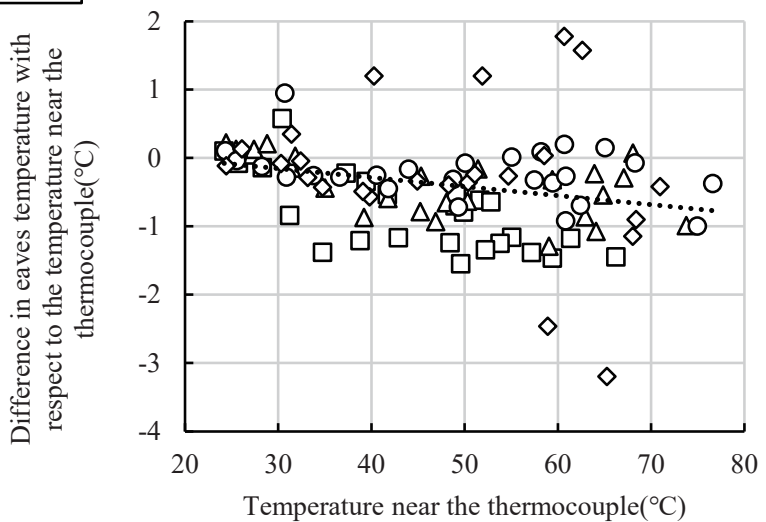

b Difference in overall roof temperature with respect to temperature near the thermocouple (Metal roof)
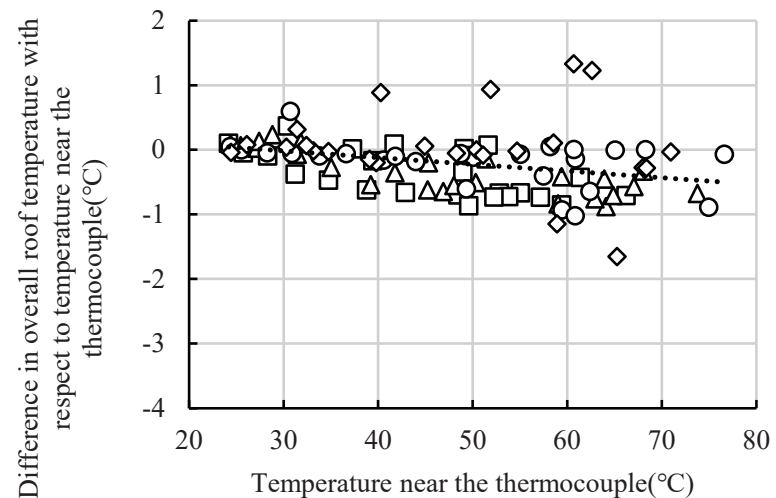
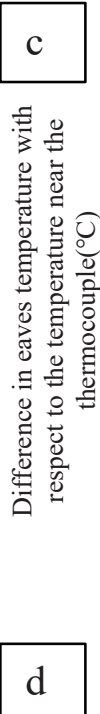

Difference in eaves temperature with respect to the temperature near the thermocouple (Tile roof)

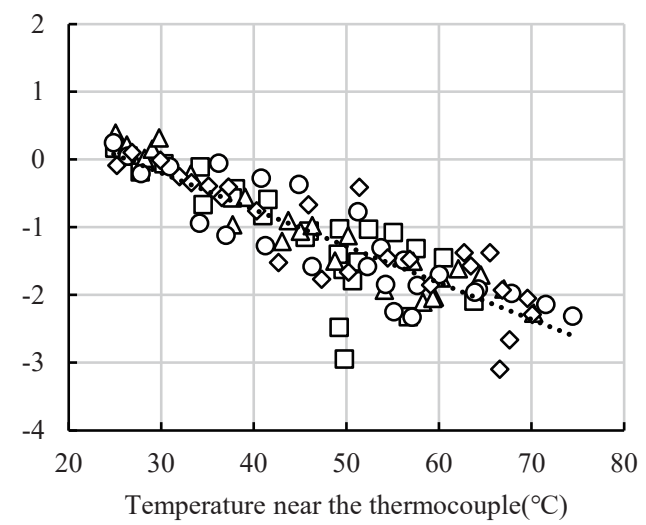

Difference in overall roof temperature with respect to temperature near the thermocouple (Tile roof)
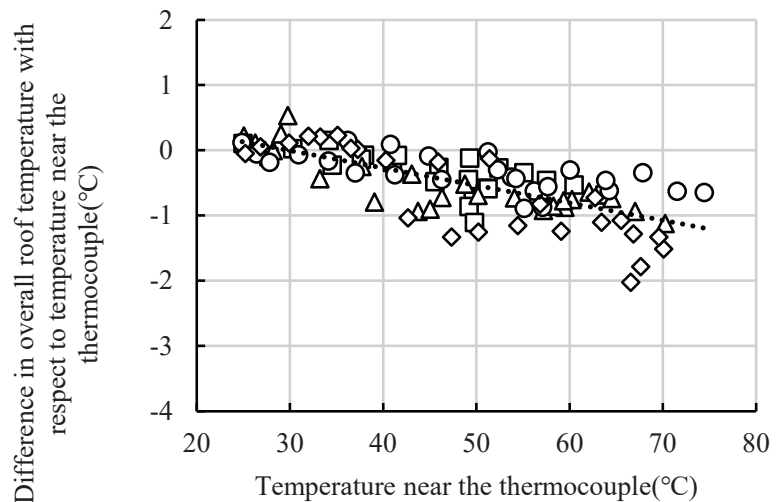

Fig. 12 Difference in eaves temperature and overall roof temperature with respect to the temperature near the thermocouple attachment position.

\begin{tabular}{cccc}
\hline North side & West side & South side & East side \\
\hline & $\Delta$ & 0 & $\diamond$
\end{tabular}

本研究の遂行にあたっては, 島根県合板協同組合に実 験住宅の利用についてご協力いただき，石州瓦工業組合 に瓦を提供いただいた。記して謝意を表す。

\section{参 考 文 献}

1) Y. Miyauchi, T. Nakai and S. Kawamura, "Investigation of the attic environment using a covered building model", Abstract of the 68th Annual Meeting of the Japan Wood Research Society, G15-P-01 (2018) .

2) K. Ehara and M. Sugawara, "The searching method for hotspots in the PV plants using a drone (UAV) ”, Journal of the Institute of Electrical Installation Engineers of Japan, Vol.37, No.6, pp.369-372 (2017) .

3) E.g., Japan UAS Industrial Development Association, "Unmanned aerial vehicle operator skill course textbook" (2019) .

4) Ministry of Land, Infrastructure, Transport and Tourism, Civil Aviation Bureau, "Application / examination procedure for permission / approval regarding flight of unmanned aerial vehicles", https://www.mlit.go.jp/common/001220061.pdf 